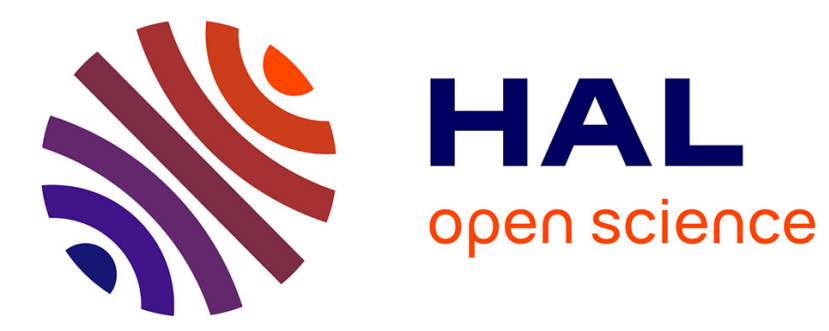

\title{
Gynogenesis caused by ultraviolet irradiation of salmonid sperm \\ Daniel Chourrout
}

\section{To cite this version:}

Daniel Chourrout. Gynogenesis caused by ultraviolet irradiation of salmonid sperm. Journal of Experimental Zoology, 1982, 223 (2), pp.175-181. 10.1002/jez.1402230209 . hal-01600635

\section{HAL Id: hal-01600635 \\ https://hal.science/hal-01600635}

Submitted on 2 Jun 2020

HAL is a multi-disciplinary open access archive for the deposit and dissemination of scientific research documents, whether they are published or not. The documents may come from teaching and research institutions in France or abroad, or from public or private research centers.
L'archive ouverte pluridisciplinaire HAL, est destinée au dépôt et à la diffusion de documents scientifiques de niveau recherche, publiés ou non, émanant des établissements d'enseignement et de recherche français ou étrangers, des laboratoires publics ou privés.

\section{다(1)(2)}

Distributed under a Creative Commons Attribution - ShareAlikel 4.0 International 


\title{
Gynogenesis Caused by Ultraviolet Irradiation of Salmonid Sperm
}

\author{
D. CHOURROUT \\ Laboratoire de Physiologie des Poissons, I.N.R.A.C.N.R.Z., 78350 Jouy \\ Enjosas, France
}

\begin{abstract}
Gynogenetic rainbow trout lines can be produced easily with the simple UV sperm irradiation technique detailed in this study. The dose effect on embryonic survival rate is called a pseudo "Hertwig effect" because of major differences with results of gamma irradiation: Some mixing of various karyotypes (from diploid to haploid number) were obtained with mean doses, probably because of the weak penetrating power of the ultraviolet rays. Irradiations lasting 4 minutes or more are required to produce homogeneous haploid progeny; heat shock applied to such fertilized eggs results in diploid fry of the maternal phenotype.
\end{abstract}

Dalcq and Simon ('31), working with Rana fusca, first described the embryonic mortality rate variations occurring after fertilization with UV-irradiated sperm. Pincus and Enzmann ('36) failed to induce any haploid development in rabbits using this method but Edwards ('56) working on the mouse succeeded in doing so; nevertheless, haploid mouse embryos were associated with hypodiploids and diploids within each litter produced by fertilization with irradiated sperm.

UV sperm-treatment is today used routinely to induce gynogenesis in amphibia and is used more and more often in fish (Table 1) instead of using ionizing rays that introduce problems of safety and source management in a laboratory. UV treatment can be accomplished by using ordinary germicidal lamps.

Pogany ('76) studied in detail the dose effect on embryonic survival in Rana pipiens. He showed no dose range resulting in $100 \%$ mortality, as generally occurs after gamma or $\mathrm{X}$ treatment for doses lower than haploid-inducing ones. Thus, it might be said to have obtained a pseudo "Hertwig effect," since even for the highest doses, a minority of diploid embryos was recovered, this result probably being due to the weak penetrating power of the ultraviolet rays.

Several simple methods are available to increase the treatment homogeneity: e.g., placing sperm in a thin layer or shaking of the milt sample during the irradiation. However, in many cases, details were not reported, making difficult an exact repetition of the experiments.
An interesting screen to eliminate spermatozoas escaping from UV-irradiation consists in the use and irradiation of heterologous sperm which provide precociously inviable hybrids if not irradiated. Hence, each survivor may be considered a gynogenome.

We analyzed in two recent papers (Chourrout et al., ' 80 ; Chourrout, ' 80 ) the Hertwig effect obtained after gamma irradiation of rainbow trout sperm, determined the best haploid-inducing doses, and described a technique inducing the diploidization of gynogenetic ova. Following is a resume of our work done by replacing the gamma-treatment with ultraviolet irradiation and thereby being able easily to produce gynogenetic lines.

\section{MATERIALS AND METHODS}

\section{Materials}

All the rainbow trout(Salmo gairdneri) females used were three years old and at their first sexual maturation. In experiment 6 , we used northern pike (Esox lucius) females. In each case we mixed several spawns before fertilizing. In experiments $1-3$, and 6 , we used a mixture of sperm removed from several rainbow trout males; in experiment 4, we used two yellow rainbow trout (Salmo gairdneri) males that were homozygous for a dominant depigmentation gene. In experiment 5 , sperm were

Address reprint requests to D. Chourrout, Laboratoire de Physiologie des Poissons, I.N.R.A. - C.N.R.Z., 78350 Jouy Enjosas, France 
TABLE 1. Use of UV rays to induce gynogenesis in fish and amphibia

\begin{tabular}{|c|c|c|c|}
\hline & Authors & Species & Species \\
\hline \multicolumn{4}{|c|}{ Homologous Sperm } \\
\hline \multirow{8}{*}{ Amphibians } & Jaylet ('72) & Pleurodeles waltlii & same \\
\hline & Farina ('76) & Discoglossus pictus & same \\
\hline & Nace et al. ('70) & Rana pipiens & same \\
\hline & Pogany ('76) & Rana pipiens & same \\
\hline & $\begin{array}{l}\text { Trottier and Armstrong } \\
\text { ('76) }\end{array}$ & Xenopus laevis & same \\
\hline & Kawahara ('78) & Xenopus laevis & same \\
\hline & Tompkins ('78) & Xenopus laevis & same \\
\hline & Reinschmidt et al. ('79) & Xenopus laevis & same \\
\hline Fish & Streisinger et al. ('81) & Brachydanio rerio & same \\
\hline \multicolumn{4}{|l|}{ Heterologous } \\
\hline Amphibians & $\begin{array}{l}\text { Nace et al. ('70) } \\
\text { Jaylet ('72) }\end{array}$ & $\begin{array}{l}\text { Rana pipiens } \\
\text { Pleurodeles waaltlii }\end{array}$ & $\begin{array}{l}\text { Rana clamitans } \\
\text { Salamandra salamandra }\end{array}$ \\
\hline Fish & Stanley and Jones ('76) & Ctenopharyndogon idella & Cyprinus carpio \\
\hline
\end{tabular}

TABLE 2. General experimental design

\begin{tabular}{|c|c|c|c|c|c|c|}
\hline $\begin{array}{c}\text { Exp. } \\
\text { number }\end{array}$ & $\begin{array}{c}\text { Number } \\
\text { of } \\
\text { males }\end{array}$ & $\begin{array}{c}\text { Male } \\
\text { species }\end{array}$ & $\begin{array}{c}\text { Number } \\
\text { of } \\
\text { females }\end{array}$ & $\begin{array}{l}\text { Female } \\
\text { species }\end{array}$ & $\begin{array}{l}\text { Mean number } \\
\text { of eggs/batch }\end{array}$ & Treatment \\
\hline 1 & 4 & Rainbow trout & 5 & Rainbow trout & 300 & UV 0-8 mn \\
\hline 2 & 3 & Rainbow trout & 2 & Rainbow trout & 100 & UV $0-4 \mathrm{mn}$ \\
\hline 3 & 7 & Rainbow trout & 3 & Rainbow trout & $4 \times 100$ & UV 0-8 mn \\
\hline 4 & 2 & $\begin{array}{l}\text { Rainbow trout } \\
\text { (yellow) }\end{array}$ & 2 & Rainbow trout & 500 & UV $4 \mathrm{mn} /$ heat shock \\
\hline 5 & $\begin{array}{l}6 \\
7\end{array}$ & $\begin{array}{l}\text { Coho salmon } \\
\text { Brown trout }\end{array}$ & 5 & Rainbow trout & 300 & UV $0-8 \mathrm{mn}$ \\
\hline 6 & 5 & Rainbow trout & 8 & Northern pike & 150 & UV $0-5 \mathrm{mn}$ \\
\hline
\end{tabular}

removed from brown trout and coho salmon (Oncorhynchus kisutch), followed by artificial fertilization, which consisted of mixing sperm and eggs and was followed by an immediate dilution with insemination diluent (Billard, '74) (Glycine 0.375 , TRIS $0.242, \mathrm{NaCl} 0.552$ ). Ten minutes later the eggs were transferred to a thermoregulated $\left(10^{\circ} \mathrm{C}\right)$ recirculating system; this moment is defined as zero development time.

\section{Methods}

\section{Irradiation.}

Five experiments were performed and the characteristics of each are described in Table 2 . In all cases, irradiation took place in a mattblack-painted box using a MAZDA T G 15 W/ $G$ lamp affixed to the ceiling $6 \mathrm{~cm}$ above the container bearing the sperm sample.

After several preliminary experiments, we were led to dilute $0.5 \mathrm{cc}$ of sperm in $2 \mathrm{cc}$ of a solution that prevents spermatozoa movement during irradiation (sperm diluent $+\mathrm{KC1} 0.2 \%$ ); then the $0.13 \mathrm{~cm}$ thick sample was magnetically shaken ( 2 rotations per second) during irradiation and finally used to fertilize one batch of eggs.

Heat-shock.

In experiment 4 , rainbow trout eggs were subjected to $26^{\circ} \mathrm{C}$ heat shock beginning $25 \mathrm{~min}$ utes after fertilization and lasting 20 minutes, in order to prevent second polar body extrusion.

Survival rates.

The embryonic survival rates were computed in each batch at day 25 (tail-bud stage) and the viable hatched fry were scored at day 40.

\section{Karyology.}

In experiment 2 , we performed karyological examinations of blastulae (at $72 \mathrm{hr}$ ) that had not had prior colchicine treatment; the blas- 


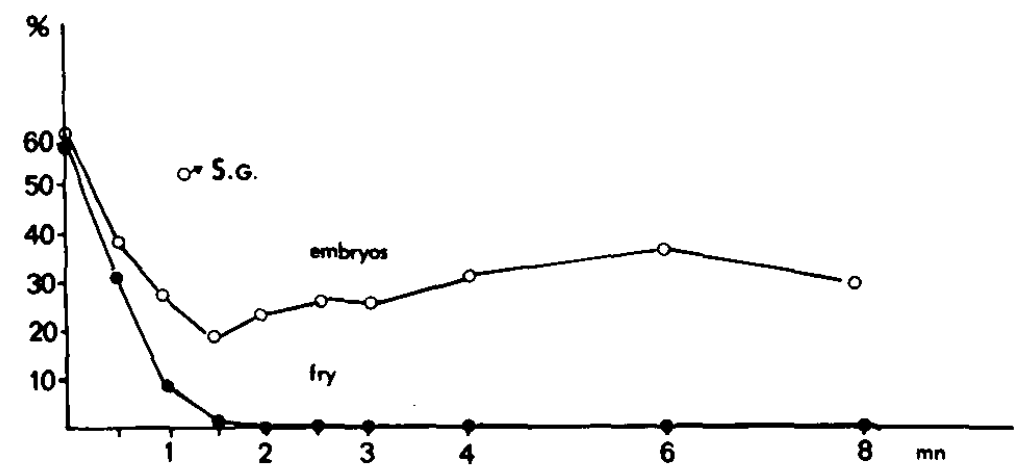

Fig. 1. Dose effect on embryonic survival and hatching rate (Exp. 1).

tulae were then fixed for 30 minutes in 3 parts ethanol to 1 part acetic acid; the blastulae were removed by dissection, rinsed in water, and then dissociated in a drop of $50 \%$ acetic acid. In experiment 4 , we examined metaphases of hatched fry that had been kept alive for $12 \mathrm{hr}$ in $0.1 \%$ colchicine solution; their gills were dissected, kept in distilled water for $\mathbf{4 5}$ minutes (hypotonic treatment), fixed 3 min in 3 parts ethanol to 1 part acetic acid, and then rinsed in water; the gill epithelium was then gently dissociated in a drop of $50 \%$ acetic acid on the slide.

In these two cases, the drop of acetic acid with cell suspension was squashed under a coverslip that was immediately removed in $50 \%$ acetic acid. The slide was rinsed and stained in $4 \%$ Giemsa for $10 \mathrm{~min}$.

\section{RESULTS}

\section{Experiment 1 (Fig. 1)}

The embryonic survival rate, computed at day 25 with respect to irradiation duration, followed a classical pattern reported in a number of similar experiments; an initial decrease down to $20 \%$ of the fertilized eggs with 0 to 1 minute doses; and a final increase in survival with increasing doses above 2 min.

An interesting observation is that increasing doses are associated with growing rates of abnormal embryos; the hatching rate percentage is positively correlated with the rate of normal embryos, and no fry were encountered after 2 min dose duration. The problem was to relate these observations with karyological results.

\section{Experiment 2 (Fig. 2 and Table 3)}

At the blastula stage, chromosomes are longer than after the gastrula stage, and it is difficult to count their number precisely. This was so even in the preliminary experiments that we performed with colchicine; nevertheless, we can present approximate results $(n \pm 3)$ and divide the metaphases into three groups:

those with more than 55 chromosomes, diploid or near diploid; those with a number between 33 and 55 , hyperhaploid to hypodiploid; and those with less than 33 chromosomes, haploid or near haploid. Thus, we may divide the dose range roughly into three parts: a duration of $15 \mathrm{sec}$ gives near diploid embryos only; a duration of $30 \mathrm{sec}, 45 \mathrm{sec}$, or $1 \mathrm{~min}$ gives all types of embryos; and a duration of $2 \mathrm{~min} 30$ $\mathrm{sec}$ or $4 \mathrm{~min}$ gives haploid or near haploid embryos only. We must give complements to these general observations: For doses between $30 \mathrm{sec}$ and $2 \mathrm{~min} 30 \mathrm{sec}$ especially, the chromosome number varied slightly within the same blastula; in addition, stained fragments that appeared similar to replicated chromosome pieces, were sometimes visible in the metaphase. It should be noted that the dose duration of 2 min $30 \mathrm{sec}$ resulted in haploid or near haploid cells, frequently containing one to three of these stained fragments; on the other hand, 4 minmetaphases contained only intact-appearing chromosomes.

\section{Experiment 3 (Table 4)}

We wished to compare the embryonic survival rates corresponding to four different high doses, resulting in zero hatching rate and supposed to induce haploid gynogenesis. For a given 


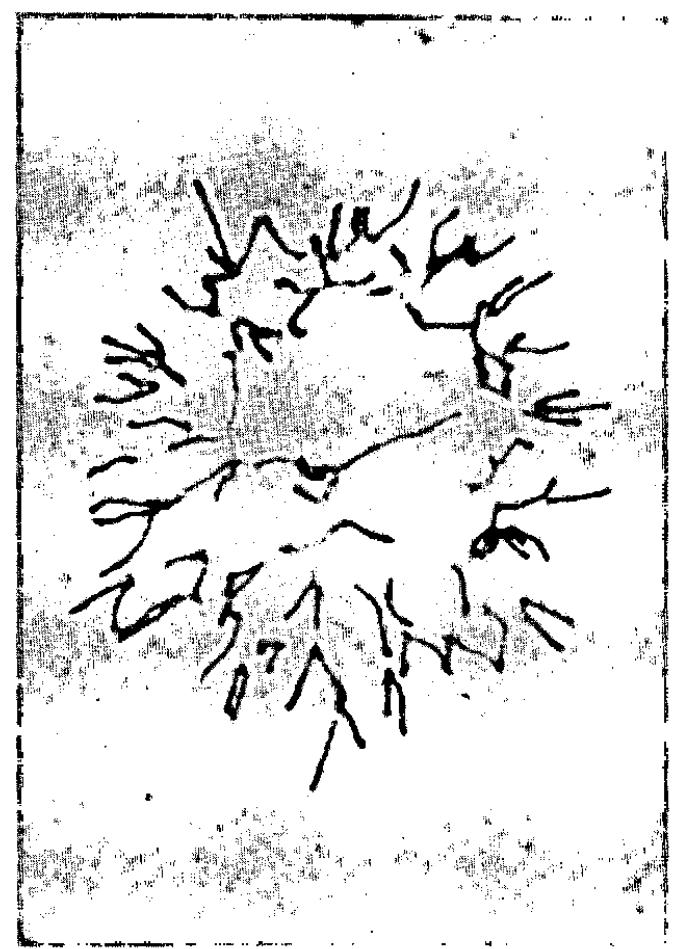

Fig. 2. Caryology at blastula stage in experiment 2. 2a : diploid or near diploid embryo; $2 \mathrm{~b}$ : near haploid cell; note stained fragments; and $2 \mathrm{c}$ : haploid cell.
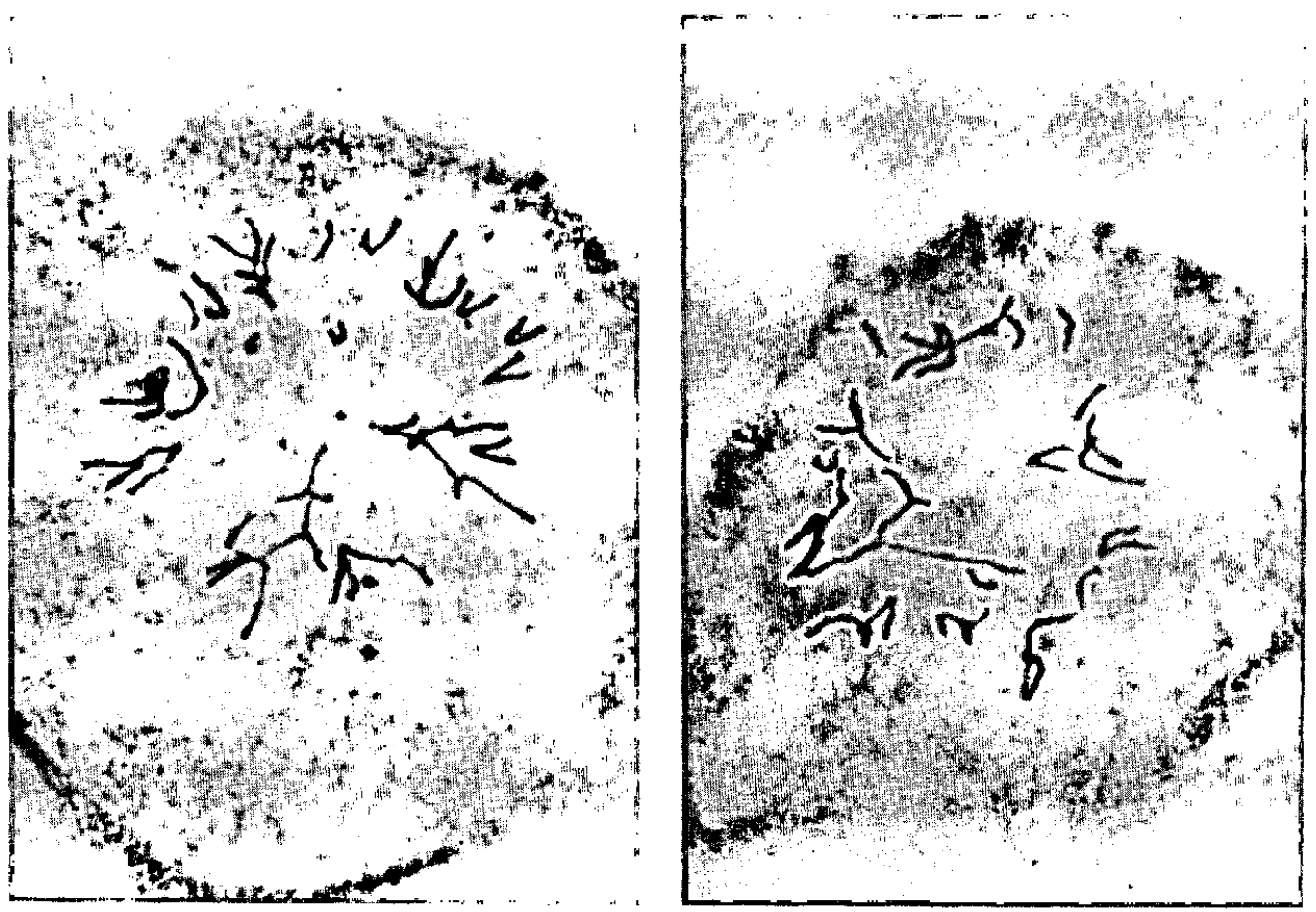

b 
TABLE 3. Caryological examinations of blastulae in experiment 2

\begin{tabular}{ccccccc}
\hline $\begin{array}{c}\text { Hatching } \\
\text { rate }\end{array}$ & UV-duration & $\begin{array}{c}\text { Number of } \\
\text { eggs }\end{array}$ & $\begin{array}{c}\text { Analyzable } \\
\text { blastulae }\end{array}$ & $\begin{array}{c}\text { Diploid or } \\
\text { near diploid }\end{array}$ & $\begin{array}{c}\text { Hypodiploid or } \\
\text { hyperhaploid }\end{array}$ & $\begin{array}{c}\text { Haploid or } \\
\text { near haploid }\end{array}$ \\
\hline $90 \%$ & $0 \mathrm{~s}$ & 10 & 10 & 10 & 0 & 0 \\
$78 \%$ & $15 \mathrm{~s}$ & 14 & 11 & 11 & 0 & 0 \\
$50 \%$ & $30 \mathrm{~s}$ & 10 & 8 & 5 & 2 & 1 \\
$23 \%$ & $45 \mathrm{~s}$ & 16 & 7 & 2 & 4 & 1 \\
$7 \%$ & $1 \mathrm{mn}$ & 22 & 15 & 7 & 3 & 5 \\
$0 \%$ & $2 \mathrm{mn} \mathrm{30} \mathrm{s}$ & 42 & 29 & 0 & 0 & 32 \\
$0 \%$ & $4 \mathrm{mn}$ & 50 & 32 & 0 & 0 & \\
\hline
\end{tabular}

TABLE 4. Embryonic survival of four doses resulting in zero hatched fry

\begin{tabular}{lrcr}
\hline UV duration & $\begin{array}{c}\text { Number of } \\
\text { eggs }\end{array}$ & $\begin{array}{c}\text { Embryonic } \\
\text { survival }\end{array}$ & $\begin{array}{c}\text { Hatched } \\
\text { fry }\end{array}$ \\
\hline $0 \mathrm{mn}$ & 100 & $53 \%$ & $50 \%$ \\
$2 \mathrm{mn}$ & 84 & $58 \%$ & $0 \%$ \\
$2 \mathrm{mn}$ & 88 & $47 \%$ & $0 \%$ \\
$2 \mathrm{mn}$ & 78 & $56 \%$ & $0 \%$ \\
$2 \mathrm{mn}$ & 77 & $44 \%$ & $0 \%$ \\
$4 \mathrm{mn}$ & & & $0 \%$ \\
$4 \mathrm{mn}$ & 80 & $39 \%$ & $0 \%$ \\
$4 \mathrm{mn}$ & 106 & $44 \%$ & $0 \%$ \\
$4 \mathrm{mn}$ & 84 & $38 \%$ & $0 \%$ \\
$6 \mathrm{mn}$ & 77 & $40 \%$ & $0 \%$ \\
$6 \mathrm{mn}$ & & $53 \%$ & $0 \%$ \\
$6 \mathrm{mn}$ & 119 & $56 \%$ & $0 \%$ \\
$6 \mathrm{mn}$ & 52 & $36 \%$ & $0 \%$ \\
$8 \mathrm{mn}$ & 86 & $34 \%$ & $0 \%$ \\
$8 \mathrm{mn}$ & 71 & $49 \%$ & $0 \%$ \\
$8 \mathrm{mn}$ & & $56 \%$ & $0 \%$ \\
$8 \mathrm{mn}$ & 68 & $39 \%$ & $0 \%$ \\
\hline
\end{tabular}

TABLE 5. Maternal transmission of pigmentation after irradiation

\begin{tabular}{lccc}
\hline \multicolumn{1}{c}{ Treatment } & $\begin{array}{c}\text { Number } \\
\text { of eggs }\end{array}$ & $\begin{array}{c}\text { Number } \\
\text { of } \\
\text { hatched } \\
\text { fry }\end{array}$ & $\begin{array}{c}\text { Fry } \\
\text { phenotype }\end{array}$ \\
\hline Control & 500 & 150 & Yellow \\
Irradiation 4 mn & 500 & 0 & black \\
Irradiation 4 mn + heat shock & 800 & 60 & \\
\hline
\end{tabular}

duration, the four different results listed in Table 4 are for four independent repetitions of irradiation, fertilization, and incubation, but with identical gametes. We did not observe any significant differences between the four tested doses.

\section{Experiment 4 (Table 5)}

The control hatching rate (unirradiated sperm, no thermal shock) was relatively low, probably because of a poor quality of the ova used; nevertheless, all the fry were yellow, thus corroborating the homozygosity of their fathers for the dominant depigmentation marker.

The batch fertilized with 4 min-irradiated sperm (without heat shock) did not produce any fry, confirming our previous observations.

The heat shock applied to eggs fertilized with 4 min-irradiated sperm and supposed to provoke the retention of the second polar body was 

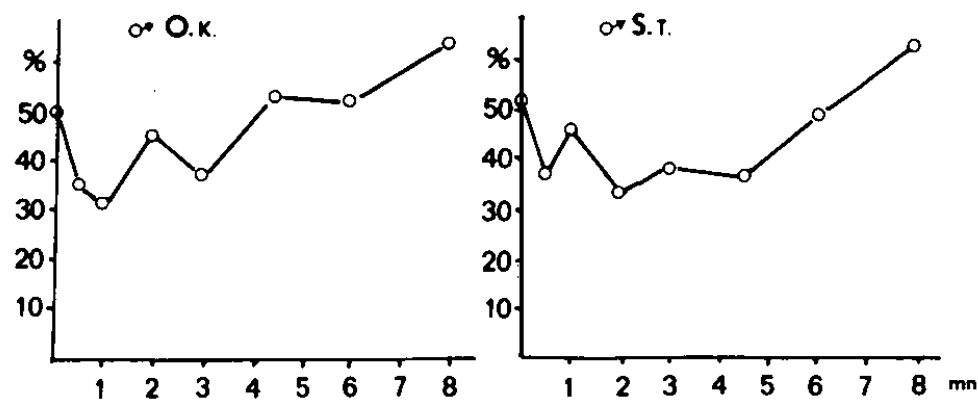

Fig. 3 Dose effect on embryonic survival in experiment 5 (sperm from Oncorhynchus kisutch and from Salmo trutta).

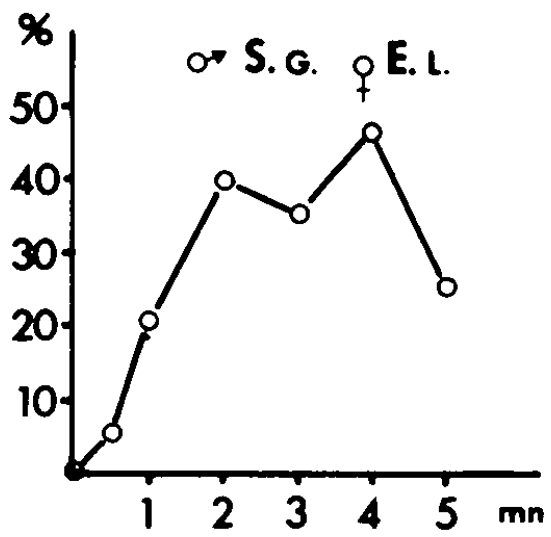

Fig. 4 Dose effect on embryonic survival in experiment 6 (Northern pike eggs and Rainbow trout sperm).

considered efficient, since the corresponding batch contained many hatched fry; all had the wild phenotype of their mother; and their karyological examination revealed only diploid metaphases, without additional chromatin-appearing points.

\section{Experiment 5 (Fig. 3)}

Rainbow trout eggs were fertilized with brown trout and coho salmon irradiated sperm, following the dose duration protocol of experiment 1 (with homologous sperm). An interesting fact is that the survival rates of those irradiated were as good as or better than those of the unirradiated controls.

\section{Experiment 6 (Fig. 4)}

In this experiment, fertilization of northern pike eggs with rainbow trout sperm provoked massive precocious abortions.
When sperm was irradiated for $30 \mathrm{sec}$, a small number of gastrulated embryos occurred in the resulting batch. This proportion increased up to $47 \%$ with higher doses.

\section{DISCUSSION AND CONCLUSIONS}

The dose effect on embryonic survival followed a pattern typically encountered in all sperm mutagen treatment experiments: an initial decrease and a final increase, the extreme doses inducing, respectively, diploid biparental and haploid gynogenetic developments. The mean doses, corresponding to the minimum rate of survival, are thought to destroy incompletely the male pronucleus and so to permit its toxic contribution to the embryonic development, perhaps because of ray-induced lethal dominant mutations.

In the case of gamma irradiation (Chourrout et al., '80), the survival rate decreased initially to zero. This minimal value, caused by a large dose range (10-80 krads), insured that diploid embryos cannot be associated with haploid ones in a same batch.

In the case of UV rays, zero survival rate is not reached for any mean dose, a fact that is clearly explained by the general karyological results of experiment 2: a mixing of diploid, hypodiploid, and haploid embryos within the same irradiated sample. There is no doubt about the direct relation between the heterogeneity of these batches and the weak penetrating power of ultraviolet radiations. An interesting result is the detection of hypodiploid (and hyperhaploid) blastulae; the slightly different chromosome numbers occurring in several cells of the same embryos indicate that irradiated chromosomes may be lost during development and, if so, certain haploid embryos could originate from pronuclear karyogamy followed by a pro- 
gressive complete loss of the paternal set. Stained fragments sometimes visible in the metaphases, even under long irradiation, may be broken chromosomes. One would expect that the elimination of male genetic material would not be limited to losses of entire chromosomes.

An important fact is that a 4 min-duration dose produced only haploid gynogenetic germs, an observation confirmed by the maternal phenotype resulting after a 4 min irradiation + heat shock in experiment 4 . It ssems that no spermatozoa escaped from the irradiation effects; on the other hand, the possibility of using higher doses (up to $8 \mathrm{~min}$ duration), that still lead to satisfactory fertilization rates points up the wide safety range of the proposed technique.

A current practice consists in fertilizing with irradiated heterologous sperm; if the diploid hybrid dies very early, it is generally agreed that all survivors are gynogenomes. We believe that two remarks must modify this approach: Since in most cases, treatment is applied to the fertilized eggs with the object of achieving polyploidy in the embryos (often at the meiosis II stage), it is absolutely necessary to verify that the same procedure, using fertilization with unirradiated heterologous sperm, produces only unviable embryos or at least individuals whose morphology is clearly different from that of the maternal species. In this respect, the case of hybridizations used in experiment 5 appears very demonstrative: The diploid hybrids of the control batch (no irradiation) do in fact hatch, but always die before feeding (Chevassus, '79). We could suppose that all survivors beyond this stage are gynogenomes; indeed, recent work in our laboratory (unpublished data) show that the corresponding triploid hybrids survive after the feeding stage, and that their external morphology cannot be easily distinguished from that of rainbow trout, at least in the first months. So, strict controls of products are absolutely necessary, even in the case of heterologous sperm irradiation. On another hand, karyological examinations of survivors must prove the lack of supernumerary paternal chromosome fragments.

The last experiment shows the Hertwig effect obtained in the case of hybridizing two more distantly related species, in which using unirradiated sperm controls cause abortion before the gastrula stage. Pending further results, we presume that all survivors beyond this stage were northern pike haploids.

\section{LITERATURE CITED}

Billard, R. (1974) L'insémination artificielle de la truite Salmo gairdneri Richardson. IV - Effets des ions $\mathrm{K}$ et $\mathrm{Na}$ sur la conservation de la fertilité des gamètes. Bull. Fr. Pisc., 256:88-100.

Chevassus, B. (1979) Hybridization in salmonids. Results and perspectives. Aquaculture, 17:113-128.

Chourrout, D. (1980) Thermal induction of diploid gynogenesis and triploidy on the rainbow trout (Salmo gairdneri Richardson). Reprod. Nutr. Dev., 20:727-733.

Chourrout, D., B. Chevassus, and F. Herioux (1980) Analysis of an Hertwig effect in the rainbow trout (Salmo gairdneri Richardson) after fertilization with gamma-irradiated sperm. Reprod. Nutr. Dev., 20:719-726.

Dalcq, A. and S. Simon (1931) Contribution a l'analyse des fonctions nucléaires dans l'ontogénèse de la grenouille. III - Etude statistique et cytologique des effets de l'irradiation d'un des gamètes sur la gastrulation chez Rana fusca. Arch. Biol. Paris, 42:107-165.

Edwards, R.G. (1956) The experimental induction of gynogenesis in the mouse. II - Ultraviolet irradiation of the sperm. Proc. R. Soc. Lond. (Biol), 146:486-504.

Farina, E. (1976) Diploid gynogenetics in Discoglossus pictus. Acta Embryol. Exp., 3:291-297.

Jaylet, A. (1972) Recherches sur diverses modifications experimentales de l'assortiment chromosomique chez le Triton Pleurodeles waltlii. Remaniement du caryotype, tetrap 1 oidie, gynogenèse. Thèse Doctorat-es Sciences Naturelles, $n^{\circ}$ 466, University Paul Sabatier, Toulouse.

Kawahara, H. (1972) Production of triploid and gynogenetic diploid Xenopus by cold treatment. Dev. Growth Differ., 20:227-236.

Nace, G.N., C.M. Richards, and J.H. Asher (1970) Parthenogenesis and genetic variability. I - Linkage and inbreeding estimations in the frog Rana pipiens. Genetics, $66: 349-368$.

Pincus, G. and E.V. Enzmann (1936). The comparative behaviour of mammalian eggs in vivo and in vitro. II: The activation of tubal egg of the rabbit. J. Exp. Zool., 73:195-208.

Pogany, G.C. (1976) Analysis of a Hertwig effect induced by the irradiation of Rana pipiens sperm with ultraviolet. Dev. Growth Differ., 18:339-348.

Reinschmidt D.C., S.J. Simon, E.P. Volpe, and R. Tompkins (1979) Production of tetraploid and homozygous diploid amphibians by suppression of first cleavage. J. Exp. Zool., 210:137-143.

Stanley, J.G. and J.B. Jones (1976) Morphology of androgenetic and gynogenetic grass carp Ctenopharyngodon idella (Valenciennes). J. Fish. Biol., 9:523-528.

Streisinger G., C. Walker, N. Dower, D. Knauber, and F. Singer (1981) Production of clones of homozygous diploid zebrafish (Brachydanio rerio) Nature, 291:293-296.

Tompkins R. (1978) Triploid and gynogenetic diploid Xenopus laevis. J. Exp. Zool., 203:251-296.

Trottier T.M. and J.B. Armstrong (1976) Diploid gynogenesis in the Mexican axolotl. Genetics, 83:783-792. 